\title{
ADAPTATION OF A TEST IN TURKISH ABOUT EVALUATION OF THE SIX YEAR OLD CHILDREN'S EMOTIONAL SKILLS: VALIDITY AND RELIABILITY STUDY
}

\author{
Neslihan DURMUŞOĞLU SALTALI* \\ M. Engin DENIZ ${ }^{* *}$ \\ Nadir ÇELIKÖ̈Z ${ }^{* * *} \quad$ Ramazan ARI***
}

\begin{abstract}
The aim of this study was to adapt the test Evaluation of six year old children's emotional skills test (identify the emotions, understand and express them.) which was developed by Schultz\& Izard (1998) to Turkish. The sampling of the study was composed of six year old 111 preschoolers who are attending four official and one private nursery school classes affiliated with the Ministry of National Education and one private nursery school. During validation process construct validity were used. During reliability process, KR 20 reliability method, item analysis, split halves, item difficulty, item differentiation, and significance test between the differentiation of top and bottom \%27 are used. At the end of this validity and reliability process six items in evaluation of emotional skills test are removed. When validity and reliability of the last version of the test examined, it is seen that it is a valid and reliable instrument to evaluate six year old children's emotional skills.
\end{abstract}

Key words: Emotional skills, emotional expression, emotional identification, emotional understanding

\footnotetext{
* Res. Asst. Selcuk University Faculty of Occupational Education, Department of Child Development, neslihan676@yahoo.com

${ }^{* *}$ Assoc. Prof. Dr. Selcuk University Faculty of Technical Education, Department of Education, engindeniz@selcuk.edu.tr

${ }^{* * *}$ Assist. Prof. Dr. Selcuk University Faculty of Occupational Education, Educational Sciences Department, ncelikoz@gmail.com

**** Prof. Dr. Selcuk University, Faculty of Occupational Education, Department of Child Development, ramazanari@hotmail.com
} 


\section{SUMMARY}

Introduction: The aim of this study is to adapt the test -Evaluation of six year old children's emotional skills test (identify emotions, understand and express them.) which is developed by Schultz\& Izard (1998) to Turkish. Emotions are inseparable part of a person's life. When you think a life without emotions life can lose its meaning easily. Everybody, even two or three year old babies, has emotions. They smile, cry, understand that they are loved, get angry, get frightened. Even just evaluating people's emotions, important information about them can be obtained. The development of the children's emotional skills starts with their birth and shows a fast progress during their early childhood. Recently, it is possible to increase the academic achievement in school by giving a child in early periods not only the mental skills but also motivation and some socio-emotional skills, they all should be combined. While characterizing a student successful, not only his academic achievement but also his abilities like understanding people's emotions, being able to control his emotions and actions, forming and maintaining a good and social relationship with his peers, teachers and people around him are also considered. Consequently, the instrument will help preschoolers' ability to identify their emotions and express them in the right way that is to say to define their emotional skills and evaluate possible lacks and eliminate these lacks, and to make the necessary changes in educational programs in this sense.

\section{Methods:}

The sampling of the study is composed of 51 female (\%45.9) and 60 male (54.1) total 111 six year old preschooler who are attending four public and one private nursery school classes that are affiliated with the Ministry of National Education. Evaluation of the six year old children's emotional skills test has three sub tests; identifying emotions, understanding emotions and expressing emotions. Identifying emotions sub test consists of 12 pictures which show emotional facial expressions (happy, sad, angry, and frightened). Understanding emotions sub-test consists of 12 sample events which tell emotional situations that children can encounter in daily life. Expressing emotions sub test consists of 12 sample events in which children show emotional expressions against the events they experienced. While determining the validity and reliability of the test, factor analysis, item difficulty, arithmetic average, standard deviation, total item correlation, item distinguishing scores were taken into consideration. 
Results: At the end of the validity and reliability process about the test considering factor analysis item difficulty, arithmetic average, standard deviation, total item correlation, item distinguishing scores two items from identification of emotions test, two items from understanding emotions test and two items from expressing emotions test were removed and the test is finalized as a 30 items test.

Discussion and Conclusion: Findings about the test's validity and reliability have shown that evaluation of six year old children's emotional skills test can be used with Turkish preschoolers to evaluate identifying emotions, understanding emotions and expressing emotions. On the other hand, to determine the test's adaptation, it is obvious that a study is needed which examines the relationship with the test and other instruments used to evaluate emotional skills whose validity and reliability are proved. Moreover, the test can be adapted in a way to evaluate different age groups' emotional skills. 


\title{
ALTI YAŞ ÇOCUKLARI İÇİN DUYGUSAL BECERILLERIN DEĞERLENDİRILMESİ TESTI'NIN (ACES) TÜRKÇEYE UYARLANMASI: GEÇERLIKK VE GÜVENIRLIK ÇALIŞMASI
}

\author{
Neslihan DURMUŞOĞLU SALTALI * $\quad$ M. Engin DENIZ ${ }^{* *}$ \\ Nadir ÇELIKÖZ ${ }^{* * *} \quad$ Ramazan ARI ${ }^{* * * *}$
}

ÖZ. Bu araştırmanın amacı Schultz ve Izard (1998) tarafindan geliştirilen altı yaş çocuklarının Duygusal Becerilerinin Değerlendirilmesi Testi'nin (duyguları tanıma, anlama ve ifade etme) Türkçeye uyarlanmasıdır. Araştırmanın örneklemini Milli Eğitim Müdürlügüne bağlı 4 resmi ve 1 özel ilköğretim bünyesinde anasınıfi ile bir özel anaokuluna devam eden 6 yaş grubu 111 anasınıfi öğrencisi oluşturmaktadır. Testin geçerlik çalışmalarında yapı geçerliği; güvenirlik çalışmalarında ise KR 20 güvenirlik metodu, madde analizi, testi yarılama, madde güçlüğü, madde ayırt ediciliği ile alt ve üst \%27 arasındaki farkın anlamlılığı testleri kullanılmıştır. Duygusal becerileri değerlendirme testi geçerlik ve güvenirlik çalışması sonucu toplam 6 madde testten çıkarılmıştır. Testin son halinin geçerlik ve güvenirlik çalışmaları incelendiğinde 6 yaş çocuklarının duygusal becerilerini ölçmede kullanılabilecek geçerli ve güvenilir bir ölçme aracı olduğu görülmüştür.

Anahtar Sözcükler: Duygusal beceri, duyguları ifade etme, duyguları tanıma, duyguları anlama

\footnotetext{
* Arş. Gör. Selçuk Üniversitesi Mesleki Eğitim Fakültesi Çocuk Gelişimi ve Ev Yönetimi Eğitimi Bölümü, neslihan676@yahoo.com

*** Doç. Dr. Selçuk Üniversitesi Teknik Eğitim Fakültesi, Eğitim Bölümü, engindeniz@selcuk.edu.tr

*** Yrd. Doç. Dr. Selçuk Üniversitesi Mesleki Eğitim Fakültesi Eğitim Bilimleri Bölümü, ncelikoz@gmail.com

**** Prof. Dr. Selçuk Üniversitesi Mesleki Eğitim Fakültesi Çocuk Gelişimi ve Ev Yönetimi Eğitimi Bölümü, ramazanari@hotmail.com
} 


\section{GİRiș}

Toplumsal yaşamın ana öğesi insan ilişkileridir. İnsan ilişkileri veya iletişim, kişilerin duygu, düşünce ve bilgilerini akla gelebilecek her türlü yolla başkalarına aktarmasıdır. İnsan insana iletişimde duyguların önemli bir yeri vardır (Yıldırım, 1999). Duygular insan yaşamının ayrılmaz parçalarıdır. Duygusuz bir yaşam düşünüldüğünde yaşam anlamını kolaylıkla yitirir. Herkes hatta birkaç aylık bebek bile duygulara sahiptir. Onlarda gülümser, ağlar, sevildiğini anlar, öfkelenir, korkarlar. Sadece duyguların değerlendirilmesiyle bile insanlar hakkında çok önemli bilgiler toplanabilir. Her duygunun güdüleyici bir özelliği, kişisel bir anlamı ve davranışlara yansıyan bir anlatımı vardır. Duygunun ifadesi evrensel olabileceği gibi kişiye özgü farklılıklar da taşıyabilir. Yüzyıllardan bu yana birçok filozof ve araştırmacı duygunun ne olduğu ile ilgili tanımlamalar ve sınıflamalar yapmaya çalışmışlar ancak duygunun tanımlanması zor bir kavram olduğu sonucunda birleşmişlerdir. Izard (1992) "Psikolojide duygusal deneyimler ve duygusal davranışlar çok tartışmalı ve tanımı güç bir alandır" diyerek bu güçlügü dile getirmiştir.

Duygu genel anlamda bireyle ilişkili öznel yaşantıları, birey için önemli olan olaylarla ilişkili olarak bireyin ne yapabileceğini, bağlam değerlendirmesini içeren, tanımlanabilir dönemleri olan bir süreç olarak tanımlanabilir (Çeçen, 2006). Duygu, iç ve/veya dış çevreden gelen etkilerin bireyde haz ya da elem türünden izlenimler oluşturmasıdır. Duygunun sürekliliği, duygunun yeğinliği ve duygunun yerleşik oluşu bireyin davranışlarına etkide bulunur. Bireyin tüm yaşamı boyunca yaptıkları etkinlikleri duyguları ile birlikte gerçekleşir. Birey, çevresindeki canlı ve cansız varlıklar ile etkileşimi sırasında, haz ya da elem yönünde, az ya da çok duygu yeğinliği içindedir (Iş̧1k, 2006). Duyguların yaşama uyum sağlama fonksiyonları vardır. Duygular, değişik durumlar ve deneyimlere tepki olarak ortaya çıkar ve her insan belli bir durum karşısında farklı şeyler hissedebilir ve tepkisini farklı bir şekilde ortaya koyabilir. Örneğin; bir ölüm karşısında kimi çok şiddetli ağlarken başka biri daha serinkanlı davranabilir (Bayhan ve Artan, 2004).

Duygusal gelişim çok yönlü etkiye açık olup sosyal, davranışsal, bilişsel, psikolojik olarak bireyin sahip olduğu özelliklerin hepsinden etkilenir. Duygusal gelişim alanında yapılan araştırmalar duygu gelişimi ile davranış gelişiminin paralellik gösterdiğini ortaya koymuştur. Okul öncesi eğitim alanında çalışan araştırmacılar bireye doğduğu andan itibaren verilecek duygulara yönelik düzenli bir eğitimin ileriki yıllarda ortaya çıkabilecek duygusal, davranışsal ve sosyal sorunları ortadan kaldıracağını bu yüzden eğitim programlarının duygusal ve sosyal içerikler yönünden 
zenginleştirilmesi gerektiğini savunmuşlardır (Ribes, Bisquerra, Agullo, Filella ve Soldevilla, 2005).

Duygusal beceriler ile sosyal beceriler arasında kuvvetli bir bă olduğundan duyguların sosyalizasyonunun anlaşılabilmesi açısından duygusal becerilerin iyi bilinmesi gerekmektedir. Duygularını doğru olarak ifade edebilme ve duygu-durum ilişkisini anlayabilme becerileri anlamına gelen duygusal farkındalık önemli bir duygusal yetenektir. Sosyal bilgi işleme modeline göre çocuklar sosyal ipuçlarını ve duyguları tanıma becerilerine güvenirlerse uygun sosyal etkileşimlere girerler (Lemerise ve Arsenio, 2000). Duyguları doğru olarak tanımlayabilme çocuğun sosyal çevresi içinde olumlu bir yer edinmesini sağlarken duygusal farkındalığa ilişkin bozukluklar örneğin öfke işaretlerini yanlış değerlendirme çocuğun sosyal ve davranışsal sorunlar göstermesine sebep olur (Fine, Trentacosta, Izard, Mostow ve Campbell, 2004).

Çocukların duygusal becerileri doğumla başlar ve erken çocukluk dönemleri boyunca hızlı bir gelişim gösterir (Denham, Blair, DeMulder, Levitas, Sawyer ve Auerbach-Major, 2003). Günümüzde okul hayatında başarının artırılması; zihinsel becerilerin yanı sıra motivasyon ve sosyoduygusal bir takım becerilerin birleştirilerek erken dönemlerden itibaren çocuğa kazandırılması ile mümkündür. Bir öğrencinin başarılı olarak nitelendirilebilmesi için yalnızca ders başarısı değil diğer insanların duygularını anlayabilme yeteneği, kendi duygu ve davranışlarını kontrol edebilmesi, akranlarıyla, öğretmenleriyle ve yakın çevresindeki bireylerle sağlıklı sosyal ilişkiler kurup devam ettirebilme yetenekleri de göz önünde bulundurulmalidır (Thompson, 2002).

Çocuklar 2-6 yaşlarında kendilerinin ve başkalarının duygularını anlamaya yönelik duygusal becerileri geliştirirler. Duygularını sözel ya da sözel olmayan yollarla ifade ederler. Çocukluk döneminin ilk yıllarında çocuklar duygularının nedenlerini, sonuçlarını ve davranışsal ipuçlarını anlayabilirler. 4-5 yaşlarından itibaren pek çok temel duyguyu doğru değerlendirebilirler. Bu dönem duygusal ifadeleri kullanmaya başladıkları dönemdir. İleriki yaşantısında çok önemli etkilere sahip olan duygusal becerilerin temeli okul öncesi dönemde atılır (Atay, 2007). Dolayısıyla okul öncesi dönem çocuklarının duyguları tanıma, duyguları anlama ve duygularını doğru şekilde ifade etme becerilerinin yani duygusal becerilerinin belirlenmesi görülebilecek eksikliklerin değerlendirilmesi ortadan kaldırılması, eğitim programlarında bu anlamda değişiklikler yapılabilmesi açısından faydalı olacaktır (Alexander, Entwisle, \& Dauber, 1993; Gagnon, Craig, Zhou, \& Vitaro, 1995)

Trentacosta ve Izard (2007) tarafindan yapılan bir çalışmada okul öncesi dönemde duygusal becerileri yüksek olan öğrencilerin okul yıllarında 
akademik başarılarının, derslerde dikkatlerinin yüksek olduğu sonucuna ulaşmışlar, araştırmacılar okul öncesi dönemde uygulanacak duygu odaklı programların çocukların dikkat ve uyumla ilgili sorunlarının erken fark edilmesi ve akademik zorlukların ortadan kaldırılması anlamında önemli olduğunu vurgulamışlardır.

Ayrıca çocukların akademik başarılarının artırılması, davranış problemlerinin önüne geçilebilmesi, olumlu akran ilişkilerinin artırılması ve okul hayatına adaptasyonla ilgili sorunlarının ortadan kaldırılması açısından da duygusal becerilerin belirlenmesi önemli bir yere sahiptir (Huffman, Mehlinger, Kerivan, Cavanaugh, Lippett ve Moyo, 2000; O’Neil, Welsh, Parke, Wang, \& Strand, 1997).

Duygusal Becerilerin Değerlendirilmesi Testi (6 yaş) çocukların duygusal zekâ gelişimlerinde önemli olan duyguları tanıma, duyguları anlama ve duyguları ifade etme becerilerini ölçmeyi amaçlamaktadır. Ölçeğin Türkçe'ye uyarlanması ve geçerlik güvenirliğinin yapılmasının Türkiye'de okul öncesi dönemdeki çocukların duygusal becerileriyle ilgili çalışmalara katkı sağlayacağı ve bu çalışmalarda ölçme aracı olarak kullanılabileceği düşünülmüştür. Çünkü mevcut literatürde okul öncesi dönem çocuklarının duygusal becerilerini ölçmeye yönelik bir ölçek bulunmamaktadır.

\section{YÖNTEM}

\section{Araştırma Grubu}

Araştırmanın örneklemini Milli Eğitim müdürlüğüne bağlı eğitim veren ilköğretim okulları bünyesindeki anasınıfları ve anaokullarında eğitim görmekte olan $51 \mathrm{kız}(\% 45.9)$ ve 60 erkek (\% 54.1) olmak üzere 6 yaş grubu toplam 111 öğrenci oluşturmuştur.

\section{Veri Toplama Aracı}

Altı Yaş Çocuklarının Duygusal Becerilerinin Değerlendirilmesi Testi (ACES: Assessment of Children's Emotion Skills)

Altı yaş çocuklarının duygusal becerilerinin değerlendirilmesi testi duyguları tanıma, duyguları anlama ve duyguları ifade etme testi olmak üzere üç alt testten oluşan bir ölçme aracıdır. Duyguları tanıma alt testi duygusal yüz ifadelerinden (mutlu, üzgün, kıgıı, korkmuş) oluşan 12 resimden oluşmaktadır. Duyguları anlama alt testi çocukların günlük hayatta karşılaşabilecekleri duygusal durumları anlatan 12 örnek olaydan oluşmaktadır. Duyguları ifade etme alt testi çocukların yaşadıkları olaylar karşısında sergiledikleri duygusal ifadelerin yer aldığı 12 örnek olaydan oluşmaktadır (Schultz ve Izard, 1998). 


\section{Çeviri}

Shultz ve Izard (1998) tarafindan geliştirilen Duygusal Becerilerin Değerlendirilmesi Testi öncelikle alanında uzman üç kişi tarafindan İngilizce'den Türkçe'ye çevrilmiş ve çeviriler karşılaştırılıp tartışılarak her maddeyi en iyi temsil eden karşıllkları ile Türkçe metin elde edilmiştir. Daha sonra bu maddeler üç İngilizce dil bilimci tarafından tekrar İngilizceye çevrilmiş ve testi ilk haliyle arasında eşdeğerlik olduğunun saptanması ile çeviri çalışması son bulmuştur. Ancak örnek olaylardan Türk kültürüyle bağdaşmadı̆̆ı düșünülen bazı maddeler üzerinde alan uzmanları tarafından değişiklikler yapılmıştır. Testte dolgu maddesi olarak yer alan ve değerlendirmede kullanılmayan maddeler alan uzmanlarının görüşleri doğrultusunda testten çıkarılmıştır.

\section{BULGULAR}

\section{Geçerlik Güvenirlik Çalıșmaları}

Schultz ve Izard (1998) tarafindan geliştirilen Duygusal Becerilerin Değerlendirilmesi Testi İngilizce formu değerlendirmeye dahil edilmeyen maddeler çıkarıldığında her bir alt test 12 maddeden oluşmak üzere toplam 36 maddeden oluşan bir testtir. Testte yer alan duyguları tanıma alt testi 12 resimden, duyguları anlama ve duyguları ifade etme alt testleri ise çocukların günlük hayatta karşılaşabilecekleri örnek olaylara dayalı 12'şer sorudan oluşmaktadır. Testin yapılan geçerlik güvenirlik çalışmaları sonrasında faktör analizi, madde güçlügü, aritmetik ortalama, standart sapma, toplam madde korelasyonu, madde ayırt ediciliği puanları göz önünde bulundurularak duyguları tanıma testinden 2 madde, duyguları anlama testinden 2 madde duyguları ifade etme testinden 2 madde çıkarılarak 30 madde olarak teste son hali verilmiştir. Testin son haline ilişkin geçerlik ve güvenirlik sonuçları aşağıda verilmiştir.

\section{Testin Geçerlik Çalışması}

Ölçeğin geçerliği yap1 geçerliği ile test edilmiştir. Testin geçerlik güvenirlik çalışmaları sırasında test Konya ili Milli Eğitim Bakanlığı bünyesinde eğitim vermekte olan resmi ve özel anaokulları ve anasınıflarına devam etmekte olan 6 yaşındaki 111 okul öncesi çocuğa uygulanmıştır.

Yapı Geçerliği: Ölçme araçlarının yapı geçerliğini belirlemede en yaygın kullanılan yöntem faktör analizidir. Faktör analizi, aynı yapıyı ölçen çok sayıda değişkenden az sayıda tanımlanabilir anlamlı değişkeni keşfetmeye yönelik çok değişkenli bir istatistiktir. Sosyal bilimlerde duyuşsal bir özelliği, kişilik ve gelişim gibi pek çok özellikleri ölçmek amacıyla geliştirilen araçların yapı geçerliği, faktör analizi kullanılarak incelenmektedir (Büyüköztürk, 2002) 
Tablo 1. Duygusal Becerileri Değerlendirme Testi Faktör Analizi Sonuçları

\begin{tabular}{cc}
\hline 1.FAKTÖR Duyguları Tanıma Maddeler & FAKTÖR YÜKÜ \\
\hline 1 & .35 \\
2 & .59 \\
3 & .36 \\
4 & .36 \\
5 & .44 \\
6 & .56 \\
7 & .38 \\
8 & .47 \\
9 & .41 \\
10 & .46 \\
\hline 2. FAKTÖR Duyguları Anlama Maddeler & FAKTÖR YÜKÜ \\
\hline 1 & .42 \\
2 & .50 \\
3 & .30 \\
4 & .32 \\
5 & .63 \\
6 & .45 \\
7 & .41 \\
8 & .38 \\
9 & .61 \\
10 & .60 \\
\hline 3.FAKTÖR Duyguları İfade Etme Maddeler & .33 \\
1 & .34 \\
2 & .53 \\
3 & .32 \\
4 & .63 \\
5 & .31 \\
6 & .38 \\
7 & .30 \\
8 & .68 \\
9 & .34 \\
\hline 10 & FAKTÖR YÜKÜ \\
\hline &. \\
\hline
\end{tabular}

Testte yap1 geçerliği için faktör analizi uygulanmadan önce örneklem uygunluğu ve Barlett Sphericity testleri gerçekleştirilmiştir. Verilerin faktör analizine uygunluğu için KMO .60'dan yüksek ve Barlett testinin anlamlı çıkması gerekmektedir (Büyüköztürk, 2004). Bu çalışmada KMO Örneklem Uygunluk katsayıs1 .64, Barlett Sphericity testi $\chi^{2}$ değeri ise 877.057 $(\mathrm{p}<.001)$ olarak bulunmuştur. Bu değerler verilerin faktör analizi için uygun olduğunu göstermektedir. Ayrıca faktör yüklerinin yeterli sayılması için .30 değeri ölçüt olarak alınmıştır. Tablo 1. incelendiğinde testin duyguları tanıma alt boyutunda faktör yüklerinin .35 ile 59 arasında; duyguları anlama alt boyutunda .30 ile .63 arasinda ve duyguları ifade etme alt boyutunda .31 ile .68 arasında değerler aldığı görülmektedir. Testin faktör yüklerinin yanı sıra, alt testlerler arasındaki korelasyonlar da incelenmiştir. Alt testlere ilişkin korelasyon katsayıları Tablo 2'de verilmiştir. 
Tablo 2. Duygusal Becerilerin Değerlendirilmesi Testi Alt testler Arası Korelasyon Katsayıları

\begin{tabular}{lccc}
\hline Faktör & Duyguları Tanıma & Duyguları Anlama & Duyguları İfade Etme \\
\hline Duyguları Tanıma & - & & \\
Duyguları Anlama & $.568^{\star *}$ & - & \\
Duyguları İfade Etme & $.428^{\star *}$ & $472^{\star *}$ & \\
\hline
\end{tabular}

$* * p<.01$

\section{Ölçeğin Güvenirlik Çalışmaları}

Testin güvenirliğinin belirlenmesinde testi yarılama, KR 20 hesaplaması, madde güçlüğü, madde ayırt ediciliği toplam madde korelasyonu, aritmetik ortalama, standart sapma, alt ve üst $\% 27$ arasındaki farkın anlamlılığı hesaplamalarından yararlanılmıştır.

\section{1) Testi Yartlama}

Testin iki yarısı arasındaki tutarlılık araştırılır. Tek numaralı sorular bir yarı, çift numaralı sorular bir yarı oluşturur. Elde edilen iki yarı; iki ayrı testmiş gibi kabul edilip aralarındaki korelasyon hesaplanır. Bu yöntem, testin bir kez uygulanmasına dayandığından kullanışlıdır. Duygusal beceri testi toplam puan ve alt testlere ilişkin testi yarılama güvenirlik sonuçlarına ilişkin istatistiksel sonuçlar ise şöyledir. Anlama alt testi için .87; tanıma alt testi için .82 ; ifade alt testi için .78 ve toplam puan için .79 olarak saptanmıştır.

\section{2) KR 20 Formülï}

Homojen bir yapıyı ölçtüğü varsayılan ve benzer maddelerden oluşan ölçme araçlarının bir tek uygulamayla güvenirliğinin belirlenmesi, o ölçme aracının iç tutarlığ 1 hakkında bilgi verir. Bir tek uygulamayla güvenirlik belirlemede çeşitli teknik ve formüller bulunmakla birlikte, en çok kullanılanları Kuder Richardson 20 (KR 20) ve Cronbach Alpha teknikleridir. Her iki teknik de birbirinden türetilmiş olmasına karşın, hangisinin kullanılacağı, madde puanlarının ölçeklenme biçimine bağlıdır (Crocker ve Algina, 1986). Madde puanları süreksiz (1-0 şeklinde) ise KR 20; sürekli (ya da sürekli kabul edildiğinde) ise Cronbach Alfa hesaplanması gerekir. KR 20 sadece doğru cevaplandırılan maddelere bir puan vererek, yanlış cevaplandırılan ve boş bırakılan maddelere ise hiç puan vermeksizin puanlanan testlere uygulanabilir. Duygusal becerilerin değerlendirilmesi testi süreksiz puan alan bir test olduğundan iç tutarlık hesaplanmasında KR 20 tekniği uygulanmıştır. Duygusal beceri testi ve alt testleri için KR 20 ile 
hesaplanan güvenirlik değerleri; tanıma alt testi için .83 , anlama alt testi için .89 ; ifade alt testi için .83 ve toplam puan için .81 olarak saptanmıştır.

\section{3) Madde Güçlüğü, Madde Ayırdediciliği}

Ayrıca maddelerin sahip oldukları psikometrik özellikleri ortaya koymak amacıyla, öğrencilerin testteki maddelere verdikleri yanıtlarla ilgili olarak aritmetik ortalama, standart sapma, toplam madde korelasyonu, madde güçlügü ve madde ayırt ediciliği hesaplanmıştır.

Madde güçlügü testte yer alan her bir maddenin doğru yanttlanma yüzdesini göstermektedir. Bu yüzde bir maddeyi doğru yanıtlayan sayısının, toplam yanıtlayıcı sayısına bölünmesiyle elde edilir ve 0.00 ile +1.00 arasında değişen değerler alabilir. Bir madde için bu değerin 1'e yaklaşması maddeyi test uygulanan kişilerin çoğunun doğru yanıtladığı ve kolay bir madde olduğu; 0'a yaklaşması da o maddeyi test uygulanan kişilerin az bir kısmının doğru yanıtladığı ve güç bir madde olduğu şeklinde yorumlanır (Tekin, 2000).

$\mathrm{Bu}$ ölçütler doğrultusunda, doğru yanıtlanma yüzdesi $0.40-0.79$ arasında olan maddeler üzerinde herhangi bir değişiklik yapılmadan alınmıştır. Doğru yanıtlanma yüzdesi 0.80 ve üzerinde olan maddeler testten çıkarılmıştır. Yanıtlanma yüzdesi 0.29 - 0.39 arasında olan maddelerin ise madde analizine bakılarak soru kökünün düzeltilmesi yoluna gidilmiştir.

Test geliştirme sürecinde, bir maddeyi bilenle bilmeyeni ayırt etme yüzdesi olarak ele alınan değer, madde ayırt edicilik indeksi olarak adlandırılır. Madde ayırt ediciliğinde test puanı yüksek olanların maddeyi doğru yanıtlamaları, test puanı düşük olanların ise maddeyi yanlış yanıtlamaları ya da boş bırakmaları istenir (Baykul, 2000). Madde ayırt edicilik indeksi -1.00 ile +1.00 arasında değişen değerler alır. İndeksin negatif değer alması, o maddeyi düşük puanlı kişilerin yanıtladığı, sıfira yakın değerler alması yüksek ve düşük puanlı eş sayıda kişinin maddeyi yanıtladığı, pozitif değer alması ise o maddeyi yüksek puanlı kişilerin yanıtladığı anlamına gelir. $\mathrm{Bu}$ nedenle ayırt ediciliği negatif ve sıfır civarında olan maddelerin testte hiç kullanılmaması gerekir. Bizim çalışmamızda da madde ayırt edicilik puanları Kutlu (2004)'e göre değerlendirilmiş ve madde ayırt edicilik indeksleri negatif olan maddelerle, 0-0.09 arasında olan maddeler testten çıkarılmış, 0.10 - 0.29 arasında olan maddeler, madde analizlerine bakılarak düzeltilmiş, 0.30 ve üzerinde olan maddeler ise üzerinde herhangi bir değişiklik yapılmadan teste alınmıştır. 
Duygusal beceri testi alt testleri ve toplam test puanına ilişkin aritmetik ortalama, standart sapma, toplam madde korelasyonu, madde güçlüğü ve madde ayırt edicilik puanları aşağıdaki tablolarda verilmiştir.

Tablo 3.1. Duyguları Tanıma Alt Ölçeğine İlişkin Güvenirlik Sonuçları

\begin{tabular}{lccccc}
\hline Maddeler & $\begin{array}{c}\text { Aritmetik } \\
\text { Ortalama }\end{array}$ & $\begin{array}{c}\text { Standart } \\
\text { Sapma }\end{array}$ & $\begin{array}{c}\text { Toplam Madde } \\
\text { Korelasyonu }\end{array}$ & $\begin{array}{c}\text { Madde } \\
\text { Gü̧̈lüğü }\end{array}$ & Ayırdedicilik \\
\hline 1 & .52 & .50 & .42 & .53 & .53 \\
2 & .64 & .48 & .60 & .65 & .63 \\
3 & .57 & .50 & .27 & .58 & .37 \\
4 & .64 & .48 & .40 & .63 & .53 \\
5 & .71 & .28 & .36 & .72 & .17 \\
6 & .61 & .49 & .59 & .60 & .60 \\
7 & .66 & .48 & .43 & .67 & .53 \\
8 & .86 & .35 & .38 & .73 & .53 \\
9 & .72 & .45 & .52 & .70 & .53 \\
\hline 10 & .45 & .50 & .28 & .55 & .57 \\
\hline
\end{tabular}

Tablo 3.1. de duygusal beceri testi duyguları tanıma alt boyutunun maddelerinin yapılan geçerlik güvenirlik çalışmaları sonrasında kalan on maddesine ilişkin aritmetik ortalama, standart sapma, toplam madde korelasyonu, madde güçlüğü ve madde ayırt ediciliği puanları verilmiştir. Bu istatistiksel değerler göz önüne alındığında ölçeğin duyguları tanıma testinde kalan on maddenin testte kullanılabilecek maddeler olduğu görülmektedir. Maddeler incelendiğinde testte çok kolay ya da zor maddenin olmadığ ancak özellikle 5. maddeye ilişkin ayırt edicilik değerinin düşük olduğu görülmektedir. Bu maddenin de madde güçlügü̈, toplam madde korelasyonu, standart sapma ve aritmetik ortalama değerleri göz önünde bulundurularak uzman görüşlerine de başvurularak testten çıkarılmamasına karar verilmiştir.

Tablo 3.2. Duyguları Anlama Alt Testine İlişkin Güvenirlik Sonuçlart

\begin{tabular}{llllll}
\hline Maddeler & $\begin{array}{l}\text { Aritmetik } \\
\text { Ortalama }\end{array}$ & $\begin{array}{l}\text { Standart } \\
\text { Sapma }\end{array}$ & $\begin{array}{l}\text { Toplam } \\
\text { Korelasyonu }\end{array}$ & $\begin{array}{l}\text { Madde } \\
\text { Gäçlüğ̈̈ }\end{array}$ & Ayırdedicilik \\
\hline 1 & .65 & .49 & .52 & .63 & .53 \\
2 & .72 & .46 & .60 & .70 & .53 \\
3 & .30 & .47 & .41 & .32 & .43 \\
4 & .50 & .50 & .37 & .53 & .47 \\
5 & .62 & .49 & .71 & .60 & .73 \\
6 & .65 & .48 & .57 & .67 & .53 \\
7 & .67 & .48 & .47 & .65 & .43 \\
8 & .36 & .45 & .27 & .38 & .37 \\
9 & .43 & .50 & .71 & .45 & .77 \\
\hline 10 & .57 & .50 & .69 & .55 & .70 \\
\hline
\end{tabular}


Tablo 3.2. incelendiğinde duygusal beceri testi duyguları anlama alt boyutuna ait maddelerin geçerlik güvenirlik sonrası kalan 10 maddesine ilişkin aritmetik ortalama, standart sapma, toplam madde korelasyonu, madde güçlüğ̈̈ ve madde ayırt ediciliği puanları görülmektedir. $\mathrm{Bu}$ istatistiksel değerler incelendiğinde testte çok kolay ya da çok zor maddenin olmadığı aritmetik ortalama, standart sapma, toplam madde korelasyonu ve ayırt edicilik değerlerinin de iyi olduğu görülmektedir. Bu da kalan on maddenin duyguları anlama becerisini ölçmede kullanılabilecek yeterlikte olduğunu göstermektedir.

Tablo 3.3. Duyguları İfade Alt Testine İlişkin Güvenirlik Sonuçlart

\begin{tabular}{llllll}
\hline Maddeler & $\begin{array}{l}\text { Aritmetik } \\
\text { Ortalama }\end{array}$ & $\begin{array}{l}\text { Standart } \\
\text { Sapma }\end{array}$ & $\begin{array}{l}\text { Toplam Madde } \\
\text { Korelasyonu }\end{array}$ & $\begin{array}{l}\text { Madde } \\
\text { Güçlüğ̈ }\end{array}$ & Ayırdedicilik \\
\hline 1 & .55 & .50 & .44 & .57 & .53 \\
2 & .26 & .44 & .35 & .27 & .40 \\
3 & .45 & .50 & .58 & .47 & .67 \\
4 & .28 & .45 & .26 & .38 & .37 \\
5 & .48 & .50 & .68 & .50 & .73 \\
6 & .38 & .49 & .40 & .40 & .53 \\
7 & .43 & .50 & .30 & .45 & .43 \\
8 & .30 & .42 & .32 & .32 & .30 \\
9 & .43 & .50 & .71 & .45 & .77 \\
\hline 10 & .36 & .48 & .44 & .38 & .50 \\
\hline
\end{tabular}

Tablo 3.3. de duygusal beceri testi duyguları ifade etme alt boyutuna ait yapılan geçerlik güvenirlik çalışmalarından sonra kalan on maddenin aritmetik ortalama, standart sapma, toplam madde korelasyonu, madde güçlügü ve madde ayırt ediciliği puanları görülmektedir. $\mathrm{Bu}$ değerler incelendiğinde kalan maddelerin duyguları ifade etme becerisini ölçmeye uygun maddeler olduğu gözlenmiştir. Duygusal beceri testinin üç alt testi toplamı oluşan duygusal beceri testinin maddelerine ilişkin istatistiksel sonuçlar tablo 3.4'te verilmiştir.

Tablo 3.4. te Duygusal Becerileri Değerlendirme Testinin geçerlik güvenirlik çalışmalarından sonra kalan 30 maddelik toplam puanına ilişkin aritmetik ortalama standart sapma, toplam madde korelasyonu, madde güçlüğü ve madde ayırt ediciliği puanları görülmektedir. Bu değerler testin duygusal becerileri ölçme konusunda güvenilir bir test olduğunu göstermektedir. 
Tablo 3.4. Duygusal Beceri Testi Toplam puanına ilişkin Güvenirlik Sonuçlart

\begin{tabular}{|c|c|c|c|c|c|}
\hline Maddeler & $\begin{array}{l}\text { Aritmetik } \\
\text { Ortalama }\end{array}$ & $\begin{array}{l}\text { Standart } \\
\text { Sapma }\end{array}$ & $\begin{array}{l}\text { Toplam Madde } \\
\text { Korelasyonu }\end{array}$ & $\begin{array}{l}\text { Madde } \\
\text { Güçlüğg̈ü }\end{array}$ & Ayırdedicilik \\
\hline 1 & .63 & .48 & .59 & .65 & .63 \\
\hline 2 & .65 & .48 & .58 & .67 & .53 \\
\hline 3 & .30 & .47 & .45 & .32 & .43 \\
\hline 4 & .55 & .50 & .32 & .57 & .33 \\
\hline 5 & .57 & .50 & .62 & .58 & .63 \\
\hline 6 & .70 & .45 & .59 & .72 & .50 \\
\hline 7 & .35 & .48 & .57 & .67 & .53 \\
\hline 8 & .42 & .44 & .33 & .35 & .30 \\
\hline 9 & .55 & .50 & .46 & .42 & .50 \\
\hline 10 & .57 & .50 & .68 & .55 & .70 \\
\hline 11 & .30 & .50 & .42 & .55 & .43 \\
\hline 12 & .37 & .45 & .35 & .30 & .32 \\
\hline 13 & .35 & .49 & .57 & .37 & .53 \\
\hline 14 & .55 & .44 & .32 & .35 & .30 \\
\hline 15 & .37 & .50 & .76 & .55 & .83 \\
\hline 16 & .52 & .49 & .37 & .37 & .40 \\
\hline 17 & .37 & .50 & .31 & .52 & .37 \\
\hline 18 & .52 & .38 & .35 & .37 & .33 \\
\hline 19 & .45 & .50 & .71 & .52 & .77 \\
\hline 20 & .52 & .50 & .49 & .45 & .50 \\
\hline 21 & .68 & .50 & .44 & .52 & .43 \\
\hline 22 & .60 & .47 & .52 & .68 & .50 \\
\hline 23 & .68 & .49 & .48 & 60 & .47 \\
\hline 24 & .92 & .47 & .33 & .68 & .30 \\
\hline 25 & .63 & .38 & .38 & .78 & .30 \\
\hline 26 & .70 & .49 & .57 & .63 & .60 \\
\hline 27 & .72 & 46 & .35 & .70 & .32 \\
\hline 28 & .68 & .46 & .45 & .70 & .40 \\
\hline 29 & .60 & .47 & .42 & .68 & .37 \\
\hline 30 & .35 & .49 & .37 & .60 & .40 \\
\hline
\end{tabular}

Alt ve Üst \%27 Arasındaki Farkın Anlamlılığı

Testin güvenirliğinin bir göstergesi olarak alt ve üst \% 27 arasındaki farkın anlamlılığına ilişkin $t$ testi yapılmıştır. Alt ve üst \% 27 arasındaki farkın anlamlılığ yönteminde geliştirilen test başarılı-başarısız iki gruba uygulanır. Başarılı grubun aldığı puanların ortalaması diğerinden anlamlı derecede büyükse test geçerlidir. Duygusal beceri testi toplam puanı ve alt test puanlarına ilişkin alt ve üst \%27 arasındaki farkın anlamlılığının yordanmasına ilişkin $\mathrm{t}$ testi sonuçları aşağıda verilmiştir. 
Tablo 4.1. Alt ve üst grupların Duyguları Tanıma Alt Testinden aldıklart puan ortalamalarının karşılaşttrılmasına Yönelik Bağımsız t Testi sonuçlart

\begin{tabular}{lcccc}
\hline Gruplar & $\mathrm{n}$ & $\mathrm{x}$ & $\mathrm{ss}$ & $\mathrm{t}$ \\
\hline Üst Grup & 30 & 8.73 & .91 & \\
Alt Grup & 30 & 3.50 & 1.01 & $21.130^{* * *}$
\end{tabular}

$* * * p<.001$

Tablo 4.1. incelendiğinde duyguları tanıma alt testinden alt ve üst \%27'lik grubun aldıkları puanların karşılaştırılmasına yönelik t testi sonuçları görülmektedir. Yapılan istatistiksel analiz sonucunda alt ve üst grup arasındaki farkın .001 düzeyinde anlamlı olduğu görülmüştür.

Tablo 4.2. Alt ve üst grupların Duyguları Anlama Alt Testinden aldiklart puan ortalamalarının karşılaştırılmasına Yönelik Bağımsız t Testi sonuçları

\begin{tabular}{ccccc}
\hline Gruplar & $\mathrm{n}$ & $\mathrm{x}$ & $\mathrm{Ss}$ & $\mathrm{t}$ \\
\hline Üst Grup & 30 & 8.79 & .96 & \\
Alt Grup & 30 & 2.97 & 1.59 & $17.044^{*}$
\end{tabular}

$* p<.05$

Tablo 4.2.'de duyguları anlama alt testinden alt ve üst \%27'lik grubun aldıkları puanların karşılaştırılmana yönelik $\mathrm{t}$ testi sonuçları görülmektedir. Yapılan istatistiksel analiz sonucunda alt ve üst grup arasındaki farkın .05 düzeyinde anlamlı olduğu görülmüştür.

Tablo 4.3. Alt ve üst grupların Duyguları İfade Etme Alt Testinden aldıkları puan ortalamalarının karşılaştırılmasına Yönelik Bağımsız t Testi sonuçları

\begin{tabular}{lcccc}
\hline Gruplar & $\mathrm{n}$ & $\mathrm{x}$ & $\mathrm{Ss}$ & $\mathrm{t}$ \\
\hline Üst Grup & 30 & 7.10 & 1.18 & \\
Alt Grup & 30 & 1.47 & .57 & $23.459^{* *}$ \\
\hline
\end{tabular}

$* * p<.005$

Tablo 4.3. incelendiğinde duyguları ifade etme alt testinden alt ve üst \%27'lik grubun aldıkları puanların karşılaştııılmana yönelik $t$ testi sonuçları görülmektedir. Yapılan istatistiksel analiz sonucunda alt ve üst grup arasındaki farkın .005 düzeyinde anlamlı olduğu görülmüştür. 
Tablo 4.4. Alt ve üst grupların Duygusal Beceri Testinden aldıkları Toplam Puanların puan ortalamalarının karşılaştırılmasına Yönelik Bağımsız t Testi sonuçları

\begin{tabular}{lcccc}
\hline Gruplar & $\mathrm{n}$ & $\mathrm{x}$ & $\mathrm{ss}$ & $\mathrm{T}$ \\
\hline Üst Grup & 30 & 11.30 & 2.93 & \\
Alt Grup & 30 & 25.13 & 3.04 & $-17.897 * * *$ \\
\hline$* * * p<.001$ & & & &
\end{tabular}

$* * * p<.001$

Tablo 4.4.'de duygusal beceri testi toplamından alt ve üst \%27'lik grubun aldıkları puanların karşılaştırılmana yönelik $t$ testi sonuçları görülmektedir. Yapılan istatistiksel analiz sonucunda alt ve üst grup arasındaki farkın .001 düzeyinde anlamlı olduğu görülmüştür.

\section{SONUC VE ÖNERILER}

$\mathrm{Bu}$ araştırmanın amacı Schultz ve Izard (1998) Duygusal Becerilerin Değerlendirilmesi Testini Türkçeye uyarlamak ve ölçeğin geçerlik ve güvenirlik analizlerini yapmaktır. Araştırma grubu sayı bakımından istatistiksel analizlerin gerektirdiği yeterliliktedir. Testin geçerlik çalışmalarında faktör analizi ve alt testler arası korelasyon katsayıları hesaplanmıştır. Faktör analizi sonucunda faktör yükü .30'un altında kalan maddeler uzman görüşleri de alınarak testten çıkarılmıştır. Alt testler arası korelasyon katsayıları incelendiğinde ise duyguları tanıma testi ile duyguları anlama testi arasındaki korelasyon değerinin .568; duyguları tanıma testi ile duyguları ifade etme testi arasındaki korelasyon değerinin .428; duyguları anlama testi ile duyguları ifade etme testi arasındaki korelasyon değerinin ise .472 olduğu ve bu değerlere göre alt testler arasında .01 düzeyinde anlamlı bir ilişki olduğu saptanmıştır.

Güvenirlik çalışmalarında ise testi yarılama yöntemi ile elde edilen güvenirlik bulguları anlama alt testi için .87; tanıma alt testi için .82 ; ifade alt testi için .78 ve toplam puan için .79 olarak saptanmıştır. KR 20 güvenirlik metodu ile hesaplanan güvenirlik değerleri ise; tanıma alt testi için .83; anlama alt testi için .89; ifade alt testi için .83 ve toplam puan için .81 olarak saptanmıştır. Ayrıca test maddelerinin aritmetik ortalama, standart sapma, toplam madde korelasyonu, madde güçlüğü ve madde ayırt edicilik puanları değerlendirilerek yapılan madde analizi sonuçları da testin güvenirliğini destekler niteliktedir. Her bir alt testin ve test toplam puanı alt $\% 27$ ile üst $\% 27$ arasındaki farkın anlamlılığına ilişkin yapılan t testi sonuçları da testin başarılı ve başarısız grupları ayırmada yeterli olduğunu göstermiştir. 
Sonuç olarak güvenirlik ve geçerlik ile ilgili elde edilen bulgular, Altı Yaş Çocuklarının Duygusal Becerilerinin Değerlendirilmesi Testi'nin Türk öğrencilerinin duyguları tanıma, duyguları anlama ve duyguları ifade etme becerilerini ölçmek için kullanılabileceğini göstermektedir. Ancak testin uyum geçerliğini belirlemek amacıyla, duygusal becerilerle ilişkili olabilecek yapıları değerlendiren ve geçerlik ve güvenirliği kanıtlanmış ölçme araçları ile bu test arasındaki ilişkilerin inceleneceği bir çalışmaya ihtiyaç duyulduğu ortadadır. Ayrıca testin farklı yaş gruplarının duygusal becerilerinin değerlendirilebileceği şekilde uyarlamaları yapılabilir.

\section{KAYNAKÇA}

Alexander, K. L., Entwisle, D. R. ve Dauber, S. L. (1993). First grade classroom behavior: Its short and long-term consequences for school performance. Child Development, 64, 801-814.

Atay, M. (2007). Çocukluk Döneminde Gelişim, Kök Yayıncılık, Ankara.

Bayhan, P. ve Artan, İ. (2004). Çocuk Gelişimi ve Eğitimi. Morpa Kültür Yayınları, İstanbul.

Baykul, Y. (2000). Eğitimde ve Psikolojide Ölçme, Klasik Test Teorisi ve Uygulaması, ÖSYM Yayınları, Ankara.

Büyüköztürk, Ş. (2002). Faktör Analizi: Temel Kavramlar ve Ölçek Geliştirmede Kullanımı, Eğitim Yönetimi Dergisi, Güz: 430-477

Büyüköztürk, Ş. (2004). Veri Analizi El kitabl, Pegem A Yayınc1lı, Ankara.

Crocker, L. ve Algina, J. (1986). Introduction to Classical and Modern Test Theory, Holt, Rinehart and Winston, New York.

Çeçen, A.R. (2006). Duyguları Yönetme Becerileri Ölçeğinin Geliştirilmesi: Geçerlik ve Güvenirlik Çalışmaları, Türk Psikolojik Danısma ve Rehberlik Dergisi, 3(26), 101-113.

Denham, S. A., Blair, K. A., DeMulder, E., Levitas, J., Sawyer, K., Auerbach-Major, S. (2003). Preschool emotional competence: Pathway to social competence? Child Development, 74, 238-256.

Fine, S.E., Trentacosta, C.J., Izard, C.E., Mostow, A.J. ve Campbell, J.L. (2004). Anger Perception, Caregivers' Use of Psysical Discipline and Aggression in Children at Risk. Social Development, 13, 213-228.

Gagnon, C., Craig, W. M., Tremblay, R. E., Zhou, R. M. ve Vitaro, F. (1995). Kindergarten predictors of boys' stable behavior problems at the end of elementary school. Journal of Abnormal Child Psychology, 23(6), 751-766. 
Huffman, L. C., Mehlinger, S. L., Kerivan, A. S. Cavanaugh, D. A., Lippett, J. ve Moyo, O. (2000). Off to a good start: Research on the risk factors for early school problems and selected federal policies affecting children's social and emotional development and their readiness for school. Chapel Hill, NC: University of North Carolina, FPG Child Development Center.

Işık, B. (2006). Ailenin örgütsel ve yapısal niteliğinin 60-72 aylık çocukların sosyal-duygusal uyum düzeyine etkisi, Yayınlanmamış Yüksek Lisans Tezi, Marmara Üniversitesi, Eğitim Bilimleri Enstitüsü, İstanbul.

Izard, C. E. (1992). Basic Emotions, Relations Among Emotion Cognition Relations, Psychological Rewiev, 99, 561-565.

Kutlu Ö, (2004).Ölçme ve Değerlendirme Dersi Yayımlanmamış Ders Notları. Ankara Üniversitesi Eğitim Bilimleri Fakültesi, Ankara.

Lemerise, E.A. ve Arsenio, W.F. (2000). An Integrated Model of Emotion Processes and Cognition in Social Information Processing, Child Development, 71, 107-118.

O’Neil, R., Welsh, M., Parke, R. D., Wang, S., ve Strand, C. (1997). A longitudinal assessment of the academic correlates of early peer acceptance and rejection. Journal of Clinical Child Psychology, 26, 290-303.

Ribes, R., Bisquerra, R., Agullo, M., J., Filella, G. ve Soldevilla, A. (2005). An Emotional Curriculum Proposal For Early Childhood Education (3 to 6 Years), Cultura y Educación, 17(1), 5-17.

Schultz, D. Ve Izard, C.E. (1998). Assessment of Children's Emotion Skills, Yayınlanmamış Araştırma Raporu, Delaware Üniversitesi, Newark.

Tekin, H.(2000). Ĕgitimde Ölçme Değerlendirme. On dördüncü Baskı, Yarg1 Yayınevi, Ankara.

Thompson, R.A. (2002). The roots of school readiness in social and emotional development. Set for Success: Building a strong foundation for school readiness based on the social-emotional development of young children, Kansas City, MO: The Ewing Marion Kauffman Foundation.

Trentacosta, J.C. ve Izard, C. E. (2007). Kindergarten children's emotion competence as a predictor of their academic competence in first grade, Emotion: Feb.7(1): 77-88.

Yıldırım, S.S. (1999). Zihin engelli çocukların duygusal yüz ifadelerini tanıma durumlarının değerlendirilmesi, Yayınlanmamış Doktora Tezi, Anadolu Üniversitesi, Eskişehir. 